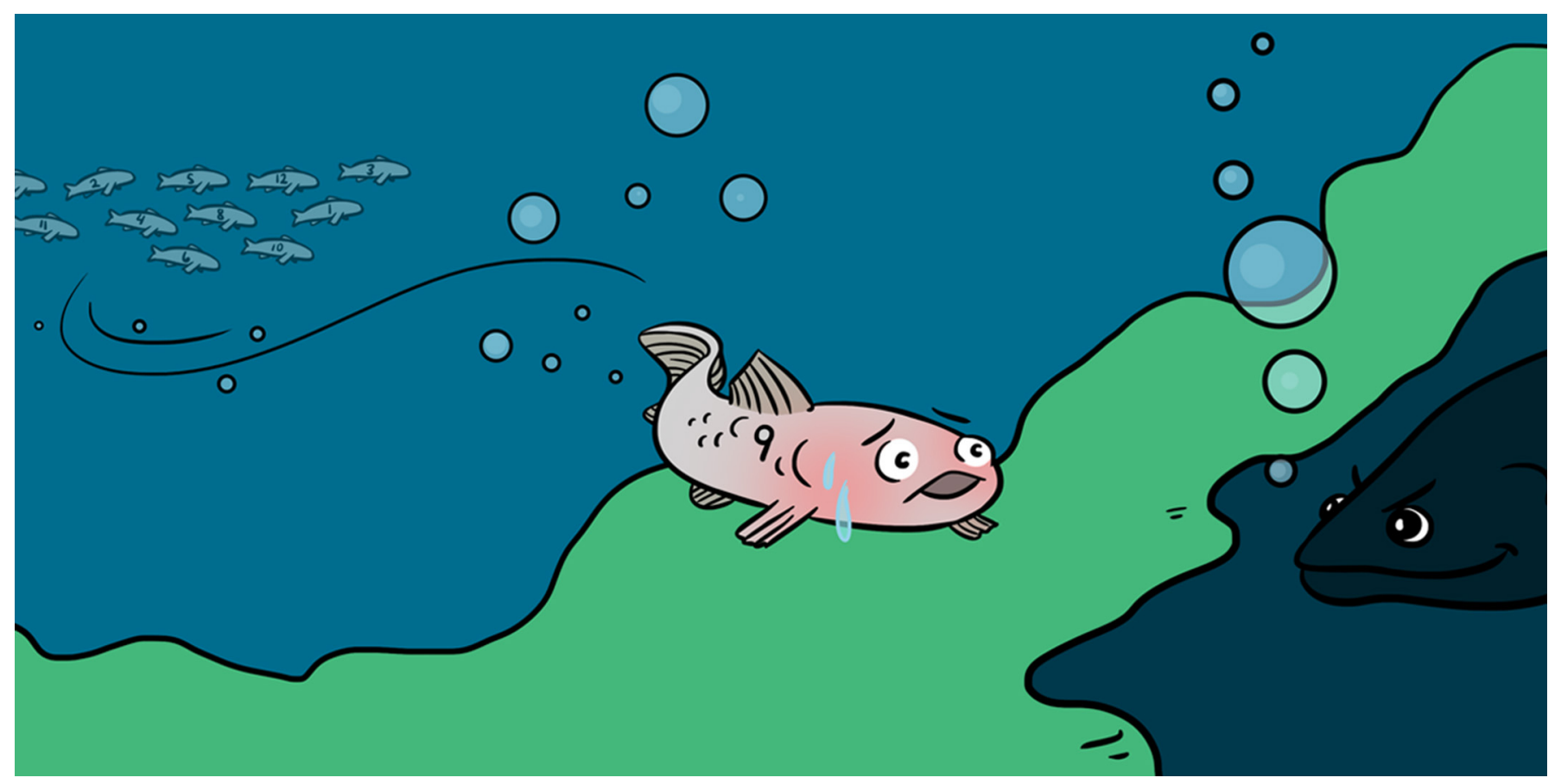

\title{
A FISH STORY: HOT WATER AND DANGEROUS BEHAVIOR!
}

\author{
Brittany E. Davis ${ }^{1 *}$, Ted Sommer ${ }^{1}$, Nann A. Fangue ${ }^{2 *}$ and Anne E. Todgham ${ }^{3 *}$ \\ ${ }^{1}$ Division of Integrated Science and Engineering, California Department of Water Resources, West Sacramento, CA, \\ United States \\ ${ }^{2}$ Department of Wildlife, Fish and Conservation Biology, University of California, Davis, Davis, CA, United States \\ ${ }^{3}$ Department of Animal Science, University of California, Davis, Davis, CA, United States
}

\section{YOUNG REVIEWERS:}

ANUSHA

AGE: 9

SABRINA

AGE: 13
Climate change is warming up water all over the world, including in the San Francisco Estuary. This has caused fish who live there to change their behavior in unexpected ways. All animals, including fish, have regular and specialized behaviors that help them to survive. Fish swim, by themselves or in groups, to move to safer habitats, to find food or mates, or just to avoid danger. Scientists worry that changes to these behaviors brought on by warming water will make estuaries less safe for rare and endangered fish like the delta smelt. In the San Francisco Estuary, we found that warmer waters caused delta smelt to swim faster and further away from their neighbors, and to be eaten more often by predators. All these changes could hurt the ability of delta smelt to survive in the future. 


\section{ENDOTHERM}

An animal that controls its body temperature from the inside, so that body temperature is different from that of the outside environment.

\section{ECTOTHERM}

An animal that cannot control its body temperature from the inside, so its body temperature and the outside temperature are the same.

\section{EXTINCTION}

The elimination of an entire species from everywhere on Earth.

\section{WHAT HAPPENS AS TEMPERATURES GET WARMER?}

California has a Mediterranean climate, which means we experience all the seasons including mild, wet winters; spring; dry, hot summers; and fall. When it stops raining and temperatures start to warm up, we can enjoy more outside activities. During warm summers, families might play sports, go to the mountains to camp or hike, or maybe go to the beach, lake, or river for boating or fishing.

Although warm summer temperatures are fun for humans, they may not be safe for fish. Warm temperatures can be quite dangerous to fish if they cannot move to a cooler place or adjust their body temperatures. Humans are okay when it is warm outside because human body temperature is not regulated by the outside temperature. We are endotherms, meaning our temperature regulation comes from inside our bodies. Most fish cannot control their body temperatures the way humans can and, as a result, their bodies are the same temperature as their environments. They are called ectotherms, meaning their temperature regulation comes from the outside.

Since ectothermic fish cannot control their body temperatures, warm water temperatures can be very stressful, causing the fish to be sick or act strangely. Hot temperatures do not just affect a single fish; warming can also affect how fish interact with their friends and enemy predators! When an individual fish swims faster or darts around acting scared, it can alter how its friends behave and change how they function as a group [1]. Fish often swim together in large numbers, in groups called schools, and schooling behavior provides fish with protection. When changes to the entire group happen, such as when the fish do not stay close together, it can make them more likely to be injured or eaten by predators.

\section{WHY ARE WE CONCERNED ABOUT WARM TEMPERATURES IN THE SAN FRANCISCO ESTUARY?}

The San Francisco Estuary is where freshwater rivers meet the salty ocean. It includes all the rivers and bays in the Sacramento, San Joaquin, Suisun, and San Francisco Bay. Scientists are worried about increasing water temperature in the Estuary because several fish species that live there are important indicators of the healthiness of the Estuary [2]. Several native fish species have already been shown to be sensitive to warm temperatures [3], and some of these species are threatened or endangered, meaning they are at risk of extinction.

One example of an endangered fish in the Estuary is the delta smelt (Hypomesus transpacificus). Delta smelt are small fish that used to be very abundant in the Estuary but, because of all the negative changes to their habitat, they are now rare and might go extinct $[4,5]$. We suspect that warm temperatures might be one factor 
contributing to the decline of delta smelt. Climate change is increasing this threat, as it is expected to continue to cause warmer air and water temperatures.

Water temperature is controlled by air temperature in the Estuary. This means that during dry, hot summers, heat waves can really warm up the water and therefore increase the body temperatures of delta smelt. This can make delta smelt unhealthy or impair their abilities to fight for food or escape from predator fish. Delta smelt have been shown to be sensitive to warm water temperatures but, prior to our study, no one had tested how the behavior of these fish changes in response to warm water, or if warm water might lead to a higher chance of being eaten by predators. So, we decided to perform experiments to study these things!

\section{TESTING THE EFFECTS OF WARM WATER ON DELTA SMELT}

To understand if a warm water temperature changes the behavior of delta smelt, we conducted experiments in which we placed 12 fish in a large tank, raised the water temperature to a warm $21^{\circ} \mathrm{C}$, and video recorded the fish to measure their behaviors for a week. We focused on how warm water changed three types of fish behavior: (i) individual and group schooling behavior, (ii) their reaction to alarming smells that mimicked an injured fish or a predator fish, and lastly (iii) how well the smelt could avoid a predator. For the predation experiment, we added one largemouth bass into each tank of 12 delta smelt. We video recorded this experiment overnight and, in the morning, counted how many delta smelt were injured or eaten by the bass. We performed each type of experiment six times, so that we had enough evidence to tell if the fish were consistently affected by warm temperatures. We also made all our observations at a normal, cool-water temperature of $17^{\circ} \mathrm{C}$, to make sure the warm water was the cause of the smelts' behavioral changes.

\section{WARM WATER MAKES DELTA SMELT BEHAVE DIFFERENTLY}

We found that warmer water temperatures negatively impacted behavior and survival of delta smelt. We saw that, in warm water, the smelt swam faster (Figure 1A). They also did not swim as close to their neighbors and instead became more spread out (Figure 1B). When we added the smell of an injured fish, delta smelt showed a somewhat normal response of swimming fast and trying to escape, but they never calmed back down after the smell was gone, the way fish in cooler water do (Figure 2). This means that smelt in warm water may continue to swim fast and panic unnecessarily, tiring themselves out. Then, they might not have enough energy left to swim away from an 
Figure 1

Warm water changes the behavior of delta smelt in dangerous ways. (A) Warm water increases the swimming speed of delta smelt. (B) Warm water increases the distance between delta smelt swimming in a group. (C) More delta smelt are injured and attacked by a largemouth bass predator when water is warm, probably because the fish are swimming further apart and are less protected by the group. The blue bars represent normal, cool water temperatures $\left(17^{\circ} \mathrm{C}\right)$, and the red bars indicate warm water $\left(21^{\circ} \mathrm{C}\right.$ ) (Image credit: $\mathrm{T}$. Treleaven and B. Davis)

\section{TIDAL WETLANDS}

Areas that are covered in shallow water near land that grow plants and plankton (fish food) underwater and the water is replenished daily with the draining and flooding of tides.

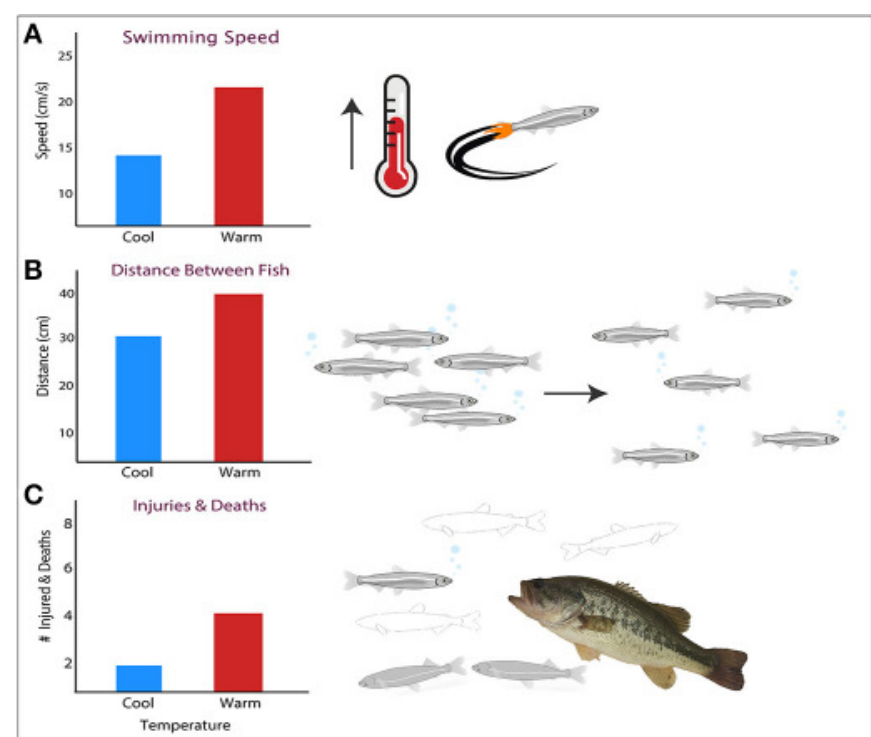

Figure 1

actual predator. Because delta smelt did not swim as close together when they were in warm water, it was easier for the predators to attack them, resulting in a doubling of the number of fish injured and eaten by the largemouth bass (Figure 1C). So, all of our results indicate that warm temperatures changed the behavior of delta smelt in harmful ways. These results provide additional evidence that warming water temperatures may be particularly bad for sensitive species like the delta smelt.

\section{CAN WE HELP FISH TO AVOID WARM WATER?}

Since higher air temperatures cause water temperatures to warm, fighting climate change is the major long-term solution to the problems faced by temperature-sensitive fish. However, there are some things we can do right now to help protect fish from warm temperatures. In upstream rivers where there are dams, the release of cool water from the deep parts of reservoirs helps keep river channels cool in the areas just below the dams. This can help fish that live in rivers, like salmon. Cooling the water is much more challenging in the Estuary where delta smelt live. There are three ideas that may hold some promise. First, some habitats like tidal wetlands and deeper pools could provide at least temporary escape from warm water. Tidal wetlands are shallow-water areas near land that have plants that grow underwater. Tides from the cooler ocean cover these areas in water every day, creating a good habitat for food to grow and for fish to find shelter. Building more tidal wetlands through habitat restoration could be an important way to support delta smelt. Habitats closer to the San Francisco Bay may be especially important since air and water temperatures tend to be a bit cooler there. Unfortunately, habitats cannot be built too close to the ocean because delta smelt cannot 
Figure 2

Delta smelt in both cool $\left(17^{\circ} \mathrm{C}\right)$ and warm $\left(21^{\circ} \mathrm{C}\right)$ water increased their swimming speeds after the smell of an injured fish was added-represented in green. But, in warm water, the fish continued to swim in a fast, panicked way even after the alarm smell was gone. This behavior could tire out the fish and make them more vulnerable to predators (Image credit: T. Treleaven and B. Davis)

\section{PLANKTON}

\section{A variety of} microscopic animals that drift in the water and provide food for other larger animals such as fish.

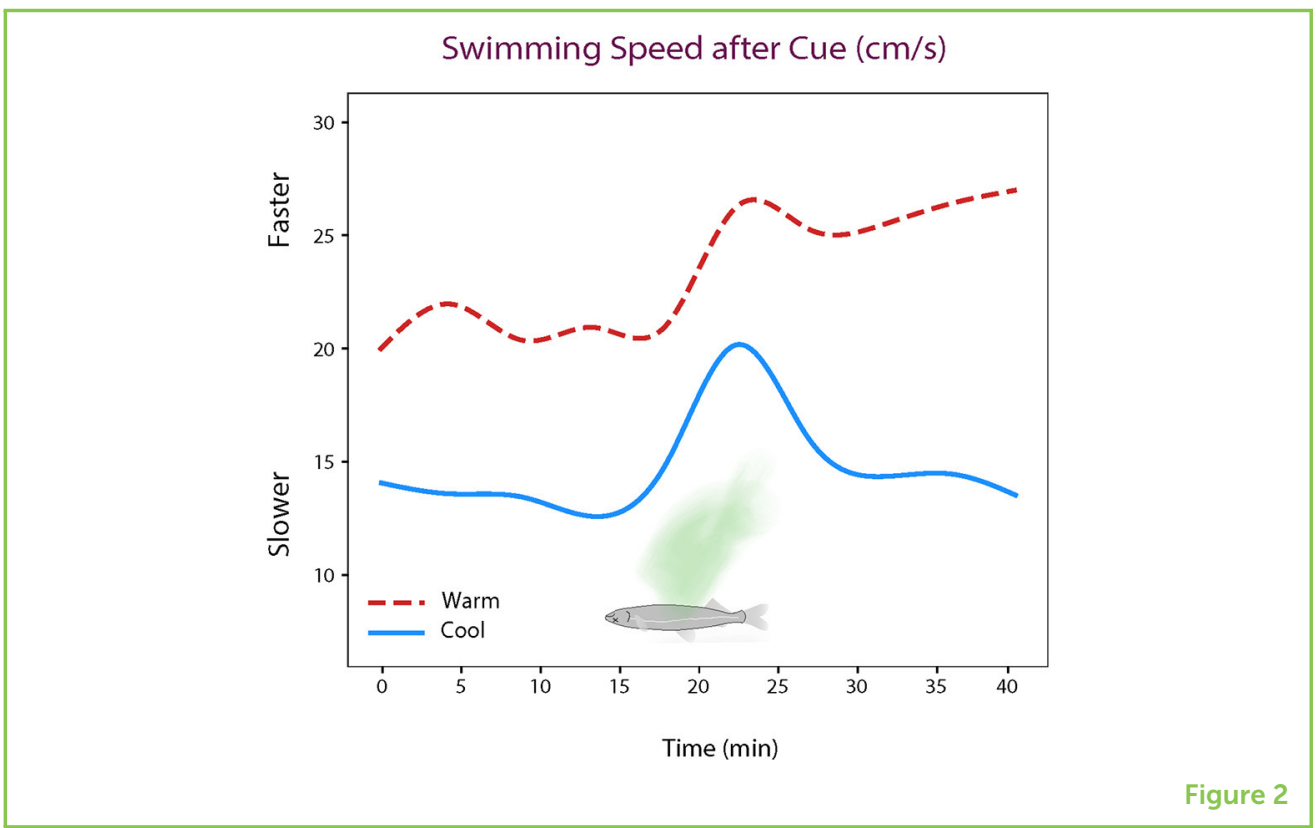

tolerate the saltiness of seawater. Second, fish tend to tolerate warm water better when they have more food. Delta smelt eat plankton. Because plankton is often scarce in the Estuary, actions that increase the amount of this important fish food could help smelt survive in warm water, at least for short periods. Building more tidal wetlands will help to increase plankton, because tidal wetlands tend to produce lots of food. Last, scientists are currently testing delta smelt that are being grown in a fish hatchery, to see if the smelts' tolerance to warmer temperatures can be increased. If so, these hatchery smelt could potentially be released into the wild someday, to help this endangered species from becoming extinct.

In summary, we found that warming water temperature, as in the San Francisco Estuary, caused delta smelt to change their swimming behavior. They swam faster, further away from their neighbors, and were eaten by predators more often than if they were in cooler water. With continued droughts in California and climate change warming up water all over the world, other species of fish are likely to also change their behavior that might be very dangerous for their survival. If fish cannot adjust to warmer temperatures, avoid predators, find enough food, or we cannot help them by providing cooler areas around the world for them to live, then it is likely more species of fish will become threatened, endangered or eventually go extinct.

\section{ORIGINAL SOURCE ARTICLE}

Davis, B. E., Hansen, M. J., Cocherell, D. E., Nguyen, T. X., Sommer, T., Baxter, R. D., et al. 2019. Consequences of temperature and temperature variability on swimming activity, group structure, and 
predation of endangered delta smelt. Freshw. Biol. 64:2156-75. doi: 10.1111/fwb.13403

\section{ACKNOWLEDGMENTS}

We would like to acknowledge the creativity of Traci Treleaven at California Department of Water Resources for helping make the figures in this article. Furthermore, we acknowledge the other scientists and fish hatchery managers that helped with the original research, as well as original funding from Delta Science Council.

\section{REFERENCES}

1. Wolf, M., and Krause, J. 2014. Why personality differences matter for social functioning and social structure. Trends Ecol. Evol. 29:306-8. doi: 10.1016/j.tree.2014.03.008

2. Sommer, T., Armor, C., Baxter, R., Breuer, R., Brown, L., Chotkowski, M., et al. 2007. The collapse of pelagic fishes in the upper San Francisco estuary. Fisheries 32:271-7. doi: 10.1577/1548-8446(2007)32[270:TCOPFI]2.0.CO;2

3. Jeffries, K. M., Connon, R. E., Davis, B. E., Komoroske, L. M., Britton, M. T., Sommer, T., et al. 2016. Effects of high temperatures on threatened estuarine fishes during periods of extreme drought. J Exp Biol. 219:1705-16. doi: $10.1242 /$ jeb.134528

4. Moyle, P. B., Brown, L. R., Durand, J. R., and Hobbs, J. A. 2016. Delta smelt: life history and decline of a once-abundant species in the San Francisco Estuary. San Francisco Estuary Watershed Sci. 14:1-30. doi: 10.15447/sfews.2016v14iss2art6

5. Hobbs, J., Moyle, P. B., Fangue, N., and Connon, R. E. 2017. Is extinction inevitable for Delta Smelt and Longfin Smelt? An opinion and recommendations for recovery. San Francisco Estuary Watershed Sci. 15:1-19. doi: 10.15447/sfews.2017v15iss2art2

SUBMITTED: 30 September 2020; ACCEPTED: 13 August 2021; PUBLISHED ONLINE: 13 September 2021.

EDITED BY: Theodore M. Flynn, California Department of Water Resources, United States

CITATION: Davis BE, Sommer T, Fangue NA and Todgham AE (2021) A Fish Story: Hot Water And Dangerous Behavior! Front. Young Minds 9:612015. doi: 10.3389/ frym.2021.612015

CONFLICT OF INTEREST: The authors declare that the research was conducted in the absence of any commercial or financial relationships that could be construed as a potential conflict of interest.

COPYRIGHT @ 2021 Davis, Sommer, Fangue and Todgham. This is an open-access article distributed under the terms of the Creative Commons Attribution License (CC 


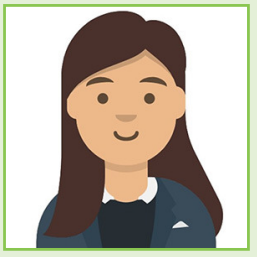

BY). The use, distribution or reproduction in other forums is permitted, provided the original author(s) and the copyright owner(s) are credited and that the original publication in this journal is cited, in accordance with accepted academic practice. No use, distribution or reproduction is permitted which does not comply with these terms.

\section{YOUNG REVIEWERS}

\section{ANUSHA, AGE: 9}

I am a 9-year-old girl and I am in 3rd grade. I love to read books, especially fantasy and science-fiction. I have finished reading the Harry Potter, Percy Jackson, Magic Tree House, The Time Machine, and The Lord of The Rings series. I want to be part of this review process because I want to continue to learn and help other kids to learn by volunteering as reviewer.

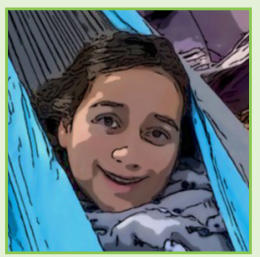

\section{SABRINA, AGE: 13}

Sabrina like swimming, backpacking, and being in hammocks. She prefers science fiction to nonfiction because it is a glimpse into what the future may be like rather than retelling what may have occurred. She has a very old and very young dog and is interested in animal behavior.

\section{AUTHORS}
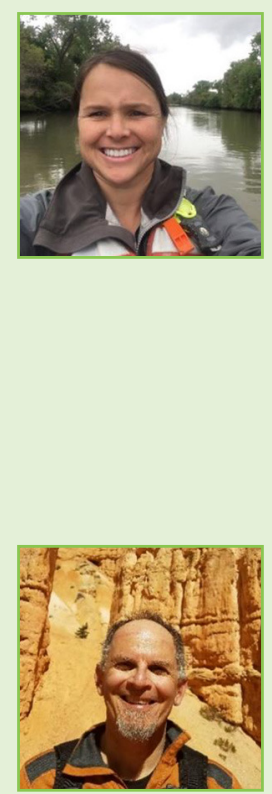

\section{BRITTANY E. DAVIS}

I am a scientist and environmental program manager for the California Department of Water Resources. My work focuses on fish and their habitats in the San Francisco Estuary. I work on projects that help us to understand how and why changes to the environment might hurt fish. I get to work with other scientists to come up with actions that will improve conditions for fish and to figure out what we can do for delta smelt, so they do not go extinct. Before the Estuary, I researched how climate change might affect fish in our oceans, near beaches, and in Antarctica. When I am not working, I like to go on outdoor adventures with my family and dog. *brittany.e.davis@water.ca.gov

\section{TED SOMMER}

Dr. Sommer is lead scientist for the California Department of Water Resources. He has worked on the San Francisco Estuary for 30 years, where his research focuses on endangered fishes and their habitats. 


\section{NANN A. FANGUE}

I am a professor of physiological ecology at the University of California Davis. In my laboratory, my students and I study fishes-especially those species that are native to California and are threatened or endangered. Our goal is to understand key biological, ecological, and physiological processes used by fishes to respond to environmental changes, to best conserve their natural habitats and ensure their survival. *nafangue@ucdavis.edu

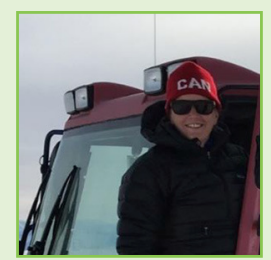

\section{ANNE E. TODGHAM}

I am a professor at the University of California Davis. As an ecological physiologist, I am interested in understanding which changes in environmental conditions fish and invertebrates like mussels, oysters, and snails find stressful, and figuring out why. Our work looks at animal physiology, behavior, and what is happening in their cells. I am particularly interested in working with young animals, as we do not think they have the same ability to cope with stress as adults do. I am lucky to conduct a lot of my research with the U.S. Antarctic Program at McMurdo Station. Antarctic fishes are particularly vulnerable to environmental changes, like ocean warming and ocean acidification, since they have lived for millions of years under extremely stable and cold ocean conditions. *todghamaucdavis.edu 